\title{
THE CARBOHYDRATE CONTENT OF SOW UTERINE FLUSHINGS
}

\author{
N. B. HAYNES AND G. E. LAMMING \\ University of Nottingham, School of Agriculture, \\ Sutton Bonington, Loughborough, Leicestershire
}

(Received 29th May 1967)

\begin{abstract}
Summary. Fructose and other carbohydrates have been identified in sow uterine flushings. The carbohydrate content has been shown to vary with the stage of the cycle.
\end{abstract}

It has been observed that the major free sugar component occurring in female reproductive tract secretions is glucose and the occurrence of fructose has not been reported except in trace quantities (Bishop, 1956; Lutwak-Mann, 1962). Unpublished observations in this laboratory have confirmed that glucose is the major free sugar in uterine flushings from the rat, rabbit, cow and sheep, and other sugars, when present, occur in much smaller amounts.

In uterine flushings of the sow, however, a different situation exists. These observations are based on uterine flushings taken from gilts penned together and examined for oestrous behaviour daily, using a boar which was not allowed to mate. The animals were not used until they had shown visible signs of two oestrous periods. They were divided randomly into four groups and uterine flushings collected at times subsequent to first standing for the boar as follows: Group 1, $6 \mathrm{hr}$ (no animal in this group had ovulated); Group 2, $48 \mathrm{hr}$ (all animals had recently ovulated); Group 3,4 days; and Group 4, 10 days. An additional group (Group 5) was added during the experiment and consisted of pigs which were examined at the second or third observed heats, but which had never ovulated and had infertile uteri.

The uterus was exposed by laparotomy under Nembutal and Fluothane anaesthesia and each uterine horn was flushed from the utero-tubal junction to the cervix with $100 \mathrm{ml}$ of a sterile saturated solution of lithium carbonate (Heap, 1962). Recoveries, based on volume of lithium carbonate varied from 65 to $100 \%$. The flushing from each horn was analysed separately. Appropriate aliquots of the flushings were subjected to chromatography on Amberlite IR-120(H) and IR-45(OH) ion exchange resins by the method of Romberger \& Norton (1961) and total sugar determinations (Trevelyan \& Harrison, 1952) were carried out on the neutral eluate. Concentrations of the eluates were subjected to descending paper chromatography in ethyl acetate-acetic acid-water $(6: 3: 1 \cdot 2 \mathrm{v} / \mathrm{v})$ and n-butanol-acetic acid-water $(40: 10: 50 \mathrm{v} / \mathrm{v})$. 
The individual constituents were identified by a variety of staining procedures and comparison with standards. Glucose and fructose were estimated by the methods of Nelson (1944) and Mann (1948), respectively, after paper chromatography and elution. Aliquots of the original flushings were investigated qualitatively for the presence of acid soluble polysaccharide material (Killingbeck, Haynes \& Lamming, 1963). The results are given in Table 1.

The difference in carbohydrate content between late oestrous secretions and others is a striking one. The total amount of carbohydrate is greater per millilitre of flushing. Further, fructose together with an unidentified material with the staining properties of a reducing sugar (unidentified carbohydrate in

TABLE 1

CARBOHYDRATE CONTENT OF UTERINE FLUSHINGS FROM PIGS AT DIFFERENT STAGES OF THE REPRODUCTIVE CYCLE

\begin{tabular}{l|c|c|c|c|c}
\hline & $\begin{array}{c}\text { Group 1: } \\
\text { early } \\
\text { oestrus }\end{array}$ & $\begin{array}{c}\text { Group 2: } \\
\text { late } \\
\text { oestrus }\end{array}$ & $\begin{array}{c}\text { Group 3: } \\
\text { early } \\
\text { luteal }\end{array}$ & $\begin{array}{c}\text { Group 4: } \\
\text { luteal }\end{array}$ & $\begin{array}{c}\text { Group 5: } \\
\text { immature } \\
\text { oestrus }\end{array}$ \\
\cline { 2 - 5 } No. of uterine horns examined & 10 & 8 & 8 & 8 & 6 \\
Total carbohydrate & $70 \pm 20$ & $291 \pm 72$ & $52 \pm 13$ & $40 \pm 3$ & $16 \pm 4$ \\
Glucose & $58 \pm 12$ & $68 \pm 16$ & $37 \pm 7$ & $38 \pm 2$ & $12 \pm 2$ \\
Fructose & Trace & $83 \pm 24$ & $10 \pm 1$ & - & - \\
Unidentified carbohydrate* & - & +++ & - & - & - \\
Pentose & - & + in four & - & - & - \\
Polysaccharide & - & $\begin{array}{c}\text { samples } \\
\text { only }\end{array}$ & & - & - \\
Inositol & samples & - & - & + \\
\hline
\end{tabular}

The results are expressed as $\mu \mathrm{g} / \mathrm{ml}$ of original flushing \pm S.E.

* Chromatographic mobility in relation to the mobility of fructose $\left(R_{\mathrm{Fr}}=1\right) 1.2$ in ethyl acetate-acetic acid-water $(6: 3: 1 \cdot 2 \mathrm{v} / \mathrm{v})$.

Table 1) and an acid soluble polysaccharide only occur in appreciable amounts at this stage of the cycle. The presence of relatively large amounts of fructose suggests that the low fructose content of pig semen (Glover \& Mann, 1954) may be compensated for by the fructose content in uterine flushings during the stage of the cycle when spermatozoa would be present.

Hydrolysis of the polysaccharide with $0.1 \mathrm{~N}$-hydrochloric acid at room temperature for $24 \mathrm{hr}$ and paper chromatography of the resulting hydrolysate revealed fructose as a constituent. The free fructose may not, therefore, be a true endometrial secretion but result from in-utero breakdown of polysaccharide. The presence of free fructose is not mirrored in parallel studies on cervical secretions where glucose is the only free sugar identifiable by paper chromatography in material collected at all stages of the cycle.

The occurrence of a polysaccharide material at oestrus is at variance with the presence of a similar material in uterine flushings from the cow and rabbit where it occurs during the luteal phase and pseudopregnancy respectively 
(Heap, 1962; Heap \& Lamming, 1963). However, its absence in pre-ovulatory oestrous animals and the immature group (5) suggests that some previous progestational activity is necessary for its presence. It has been demonstrated (Haynes, 1967) that polysaccharide material isolated from rabbit uterine flushings will actively prevent phagocytosis of spermatozoa by polymorphonuclear leucocytes in vitro. It is possible, therefore, that the presence of a similar material in the uterus of the oestrous pig would be of benefit in preventing a rapid removal of spermatozoa from the uterine environment.

This investigation was supported by a grant from the Pig Industry Development Authority.

\section{REFERENCES}

Bishop, D. W. (1956) Active secretion in rabbit oviduct. Am. F. Physiol. 187, 347.

Glover, T. \& MANN, T. (1954) On the composition of boar semen. F. agric. Sci. 44, 355.

HAynes, N. B. (1967) The infuence of the uterine environment on the phagocytosis of spermatozoa. In: Reproduction in the Female Mammal. Eds. G. E. Lamming and E. C. Amoroso. Butterworths, London.

HEAP, R. B. (1962) Some chemical constituents of uterine washings: a method of analysis with results from various species. 7. Endocr. 24, 367.

Heap, R. B. \& Lamming, G. E. (1963) An acid soluble component of uterine washings. F. Endocr. 27, 265.

Killingbeck, J., Haynes, N. B. \& Lamming, G. E. (1963) Influence of isolated components of the uterine secretion on phagocytosis. Nature, Lond. 199, 255.

Lutwak-Mann, C. (1962) Some properties of uterine and cervical fluid in the rabbit. Biochim. biophys. Acta, 58, 637.

Mann, T. (1948) Fructose content and fructolysis in semen, practical application in the evaluation of semen quality. 7. agric. Sci. 38, 323.

Nelson, N. (1944) A photometric adaptation of the Somogyi method for the determination of glucose. 7. biol. Chem. 153, 375.

Romberger, J. A. \& Norton, G. (1961) Changing respiratory pathways in potato tuber slices. $\mathrm{Pl}$. Physiol., Lancaster, 36, 20.

Trevelyan, W. E. \& Harrison, J. S. (1952) Studies on yeast metabolism. Fractionation and microdetermination of cell carbohydrates. Biochem. F. 50, 298. 